\title{
Sistem Aplikasi Pencarian Lokasi Parkir Terdekat Menggunakan Location Based Service Berbasis Android
}

\section{Nearest Parking Location Search Application System Using Location Based Service on Android}

\author{
S Nurhayati ${ }^{*}$, Egi Nur Ilmi² \\ 1,2)Program Studi Sistem Komputer \\ Fakultas Teknik dan Ilmu Komputer, Universitas Komputer Indonesia \\ Jl. Dipati Ukur No. 112 - 116, Bandung, Indonesia 40132 \\ *email: sri.nurhayati@email.unikom.ac.id
}

\begin{abstract}
The purpose of this research is to make the closest parking search application so that it can make it easier for parkers to find the nearest and empty parking lot. Parking activities that are carried out carelessly in places that are not intended will lead to traffic congestion. This happened because it was caused by the inability of vehicle users to find out about the parking places or because the existing parking lot was full. The object of this study is the location of parking lots in the city of Bandung. Analysis of the application system made in this study uses an objectbased programming approach with Unified Modeling Language (UML) tools. The Location Based Service (LBS) method is used to analyze the search for the nearest parking location. Based on the results of application testing, the application can be implemented properly on android devices and can help parking users in finding empty parking lots and the closest to the user.
\end{abstract}

Keywords - Parking, Location Based Service (LBS), Unified Modeling Language (UML), Object-Based Programming

ABSTRAK - Tujuan dari penelitian ini adalah membuat aplikasi pencarian parker terdekat sehingga dapat mempermudah pengguana parker dalam mencari tempat parker yang terdekat dan yang kosong. Kegiatan parkir yang dilakukkan secara sembarangan di tempat yang bukan peruntukannya akan menimbilkan kemacetan lalu lintas. Hal tersebut terjadi karena di akibatkan tidak tahunya pengguna kendaraan tentang info tempat - tempat parkir yang ada atau di karenakan tempat parkir yang ada sudah penuh. Objek dari penelitian ini adalah lokasi tempat parkir yang ada di Kota Bandung. Analisis dari sistem aplikasi yang dibuat pada penelitian ini menggunakan pendekatan pemrograman berbasis objek dengan tools Unified Modeling Language (UML). Metode Location Based Service (LBS) digunakan untuk menganalisis pencarian lokasi parkir terdekat. Berdasarkan dari hasil pengujian aplikasi, aplikasi dapat terimplementasi dengan baik pada perangkat android dan sudah dapat membantu pengguna parkir dalam mencari tempat parkir yang kosong dan terdekat dengan pengguna.

Kata Kunci - Parkir, Location Based Service (LBS), Unified Modeling Language (UML), Pemrograman Berbasis Objek

\section{Pendahuluan}

Tempat parkir merupakan salah satu sarana yang tidak dapat dipisahkan dari sistem transportasi. Semakin bertambahnya jumlah penduduk yang menggunakan sarana transportasi pribadi untuk melakukkan aktivitasnya menyebabkan diperlukaan jumlah tempat parkir yang memadai [1][2]. Permasalahan yang terjadi jika melakukkan parkir sembarangan akan mengakibatkan kemacetan dikarenakan pergerakan kendaraan yang melewati tempat-tempat yang beraktifitas tinggi, laju pergerakanya akan terhambat oleh kendaraan yang parkir disembarang tempat, selain itu akan 
meningkatkan resiko terjadinya kecelakaan. Permasalahan tersebut dikarenakan kurang tahunya pengendara dalam titik keberadaan lokasi parkir di tempat tujuan juga jadi faktor utama pada masalah tersebut karena tidak banyak rambu atau penunjuk arah yang menunjukan lokasi parkir di area tujuan para pengendara.

Beberapa penelitian yang telah dilakukan tentang sistem perparkiran adalah analisis karateristik dan kebutuhan ruang parkir pada pusat perbelanjaan di kabupaten Bandung, pada penelitian ini hanya dilakukan analisis standar kebutuhan ruang parkir dari sebuah pusat perbelanjaan [2]. Penelitian lain yaitu sistem informasi pelayanan parkir, pada penelitian sistem dibuat untuk memudahkan dalam layanan parkir di tempat parkir tertentu [3]. Pada penelitian ini sistem aplikasi yang akan dibuat bertujuan untuk memudahkan pengendara dalam mencari lokasi parkir terdekat dan lokasi parkir yang kosong.

Metode yang digunakan dalam pencarian lokasi parkir terdekat adalah metode LBS. Metode LBS merupakan salah satu bagian dari implementasi mobile GIS yang lebih cenderung memberikan fungsi terapan sehari-hari seperti menampilkan direktori kota, navigasi kendaraan, pencarian alamat serta jejaring sosial dibanding fungsionalitas pada teknologi GIS populer untuk Field Based GIS [4][5].

Berdasarkan permasalahan diatas maka akan dibuat sebuah aplikasi pencarian parkir terdekat menggunakan metode LBS yang bertujuan untuk memberikan kemudahan kepada pengendara dalam mencari lokasi parkir terdekat.

\section{METODE DAN BAHAN}

Data lokasi parkir yang digunakan pada penelitian ini adalah lokasi parkir yang ada di kota bandung. Peta lokasi parkir didapatkan dari Google Map yang merupakan layanan gratis untuk aplikasi peta online yang disediakan oleh Google [6]. Google Maps API digunakan untuk mengintegrasikan ke sistem yang akan dibuat.

Metode yang digunakan untuk penentuan lokasoi parkir terdekat adalah metode LBS. Metode ini digunakan untuk memberikan layanan informasi lokasi parkir berdasarkan lokasi yang terdekat dengan pengendara. Adapun tahapan pencarian menggunakan metode ini terlihat pada gambar 1, adalah sebagain berikut :

1. Mulai.

2. GetCurrentLocation / menentukan posisi asal pengguna.

3. Menghitung lokasi tempat layanan dengan posisi pengguna.
4. Memfilter lokasi layanan pada database dengan jarak 1-500m.

5. Mencari apakah ada tempat layanan terdekat.

6. Menampilkan data tempat layanan pada pengguna.

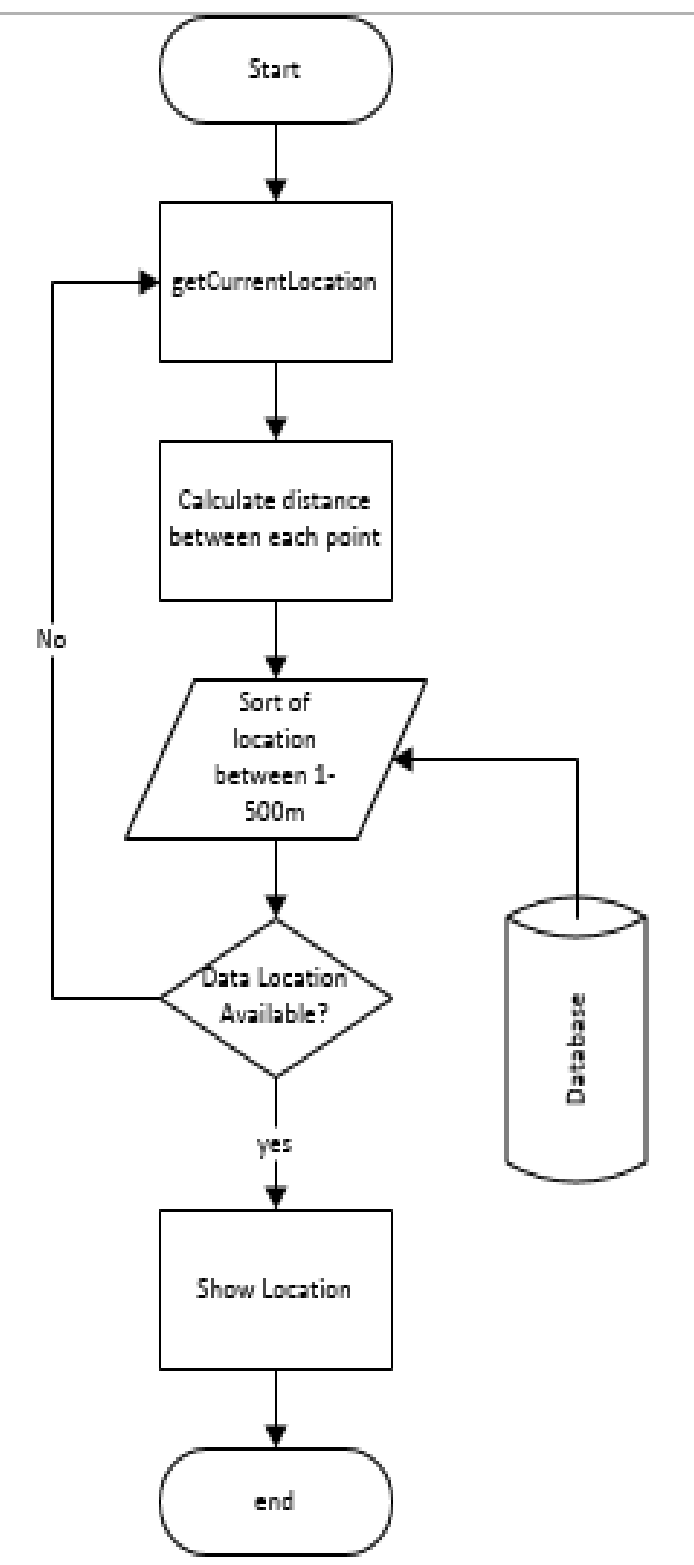

Gambar 1. Flowchat Pencarian Lokasi Parkir menggunakan LBS.

Analisis pembuatan aplikasi menggunakan pendekatan objek dengan tools UML. Tools ini merupakan tools standar yang digunakan untuk untuk mendokumentasikan, menspesifikasikan, dan membangun sistem perangkat lunak [7].

Dasar dalam perancangan dan implementasi dari system yang akan dibuat dibutuhkan spesifikasi kebutuhan [8]. Spesifikasi kebutuhan dari system aplikasi pencarian parkir terdekat terlihat pada tabel 1. 
Tabel 1. Spesifikasi kebutuhan

\begin{tabular}{ll}
\hline Kebutuhan & Use case \\
\hline $\begin{array}{l}\text { Untuk masuk ke dalam system } \\
\text { melakukan aktivitas pengolahan } \\
\text { data }\end{array}$ & \\
Untuk memasukkan data lokasi & Registrasi \\
parkir dan kapasitas parkir & \\
Melihat informasi parkir & Parkiran \\
terdekat terdekat \\
$\begin{array}{l}\text { Menampilkan rute parkir } \\
\text { terdekat }\end{array}$ & Cari parkir \\
\hline
\end{tabular}

Aplikasi dibuat ke dalam dua platform yaitu android yang digunakan untuk pengendara untuk mendapatkan informasi lokasi parkir terdekat, dan website digunakan untuk admin dalam mengelola lokasi tempat parkir.

Dari tabel 1, maka dimodelkan ke dalam sebuah use case diagram. Use case diagram ini menggambarkan apa yang dilakukkan actor terhadap sistem yang dibuat [9].

Adapun use case diagram dari sistem yang akan dibuat terlihat pada gambar 2 dan 3 .

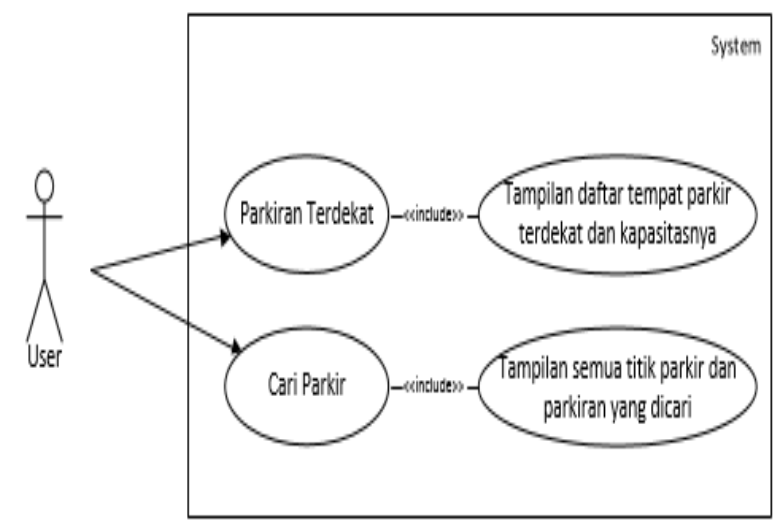

Gambar 2. Use case diagram sistem yang dibuat berbasis android.

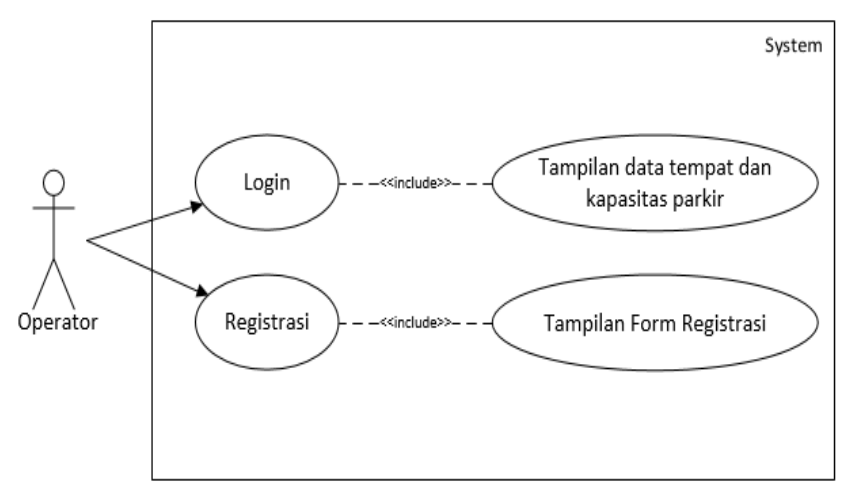

Gambar 3. Use case diagram Sistem yang dibua berbasis web.

Sketsa penggambaran dari gabungan dari elemen - elemen yang dibutuhkan untuk mewakili keadaan sebenarnya dari sistem yang dibuat disebut perancangan antar muka [10]. Rancangan antar muka untuk pengendara terlihat pada gambar 4 dan 5.

Pada saat aplikasi pertama kali dijalankan akan tertuju pada tampilan halaman utama tampak pada gambar 4. List View merupakan daftar seluruh lokasi parkir dan kapasitasnya, tampilan peta merupakan tampilan awal ketika aplikasi dijalankan.

Terdapat symbol yang merupakan sebuah button atau tombol untuk membuka menu di dalamnya yaitu parkir terdekat, dan Cari Parkir.

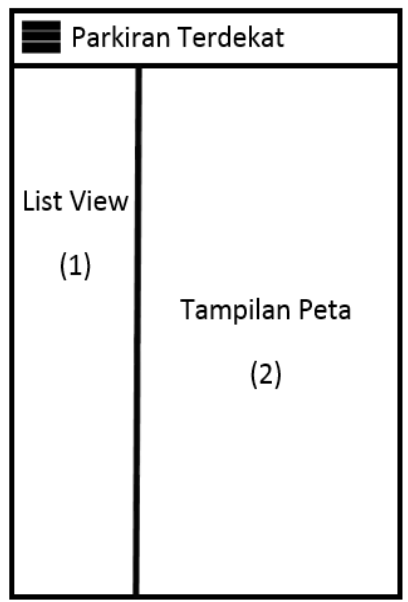

Gambar 4. Tampilan Antar Muka Menu Parkiran Terdekat.

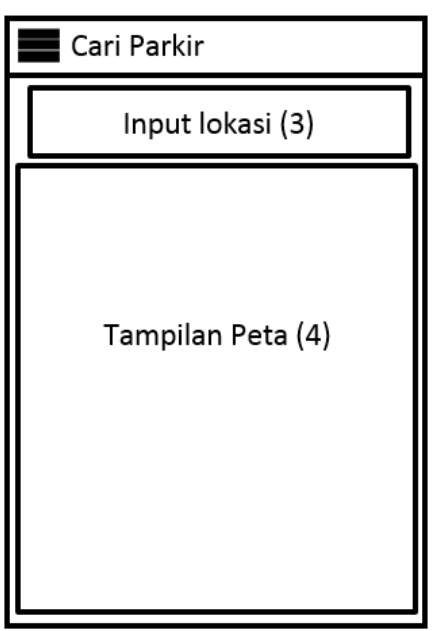

Gambar 5. Rancangan tampilan untuk menu cari parkir.

Pada gambar 5 adalah menu dari cari parkir pada menu cari parkir ini pengguna dapat mencari lokasi parker pada tujuan yang akan dituju oleh pengendara dan beserta kapasitas parkirnya.

Untuk rancangan antar muka admin terlihat pada gambar 6 dan 7. 


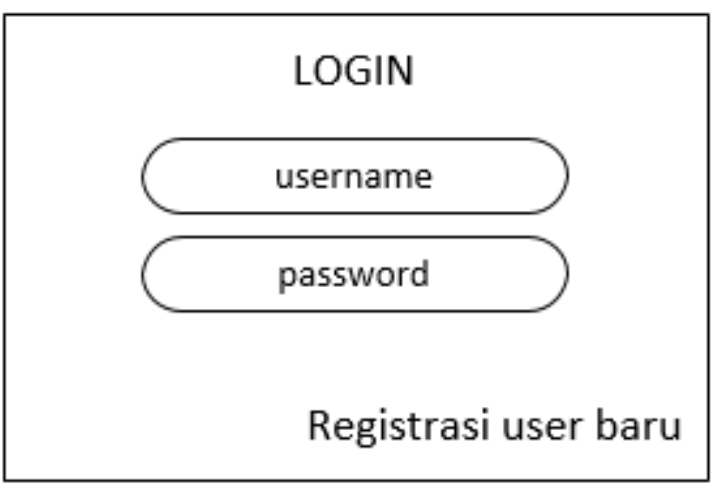

Gambar 6. Rancangan tampilan untuk halaman utama aplikasi web operator

Gambar 6 merupakan halaman utama pada aplikasi web operator, form login sebagai langkah pertama untuk penggunaan aplikasi.

Dan ada juga flying text sebagai tombol untuk registrasi operator baru.

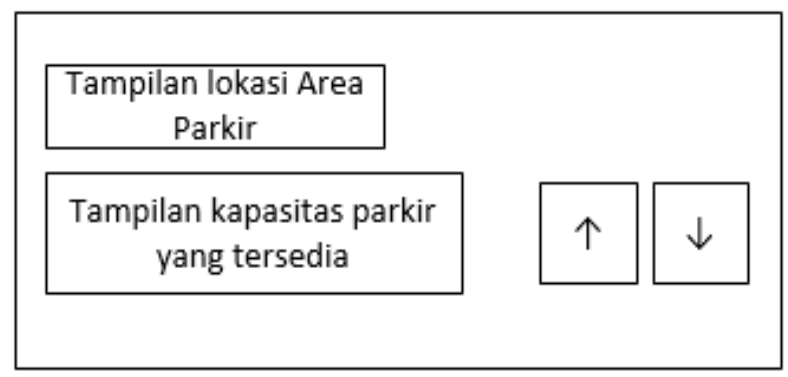

Gambar 7. Rancangan tampilan untuk monitoring ketersediaan parkir.

Gambar 7 merupakan lanjutan setelah login berhasil dan layar menampilkan monitoring ketersediaan parkir, operator dapat merubah nilai ketersediaan parkir dengan cara menekan tombol panah.

\section{HASIL DAN PEMBAHASAN}

Kebutuhan hardware yang digunakan dalam penggunaan sistem ini antara lain :

a. Aplikasi yang digunakan Pengguna (basis Android)

1. Processor Quad-core $1.2 \mathrm{GHz}$ Cortex-A7

2. RAM $1 \mathrm{~Gb}$

3. Memory $100 \mathrm{Mb}$

b. Aplikasi yang digunakan Admin (basis Web)

1. Processor Intel core i5-2430M (2.4 GHz)

2. Harddisk $750 \mathrm{~GB}$

3. RAM $4 \mathrm{~GB}$

Sistem operasi Android 5.1 (Lollipop) untuk aplikasi yang digunakan oleh pengendara, sedangkat sistem operasi yang digunakan pada aplikasi yang digunakan oleh admin adalah Windows 8.1.
Implementasi antarmuka dari sistem aplikasi yang dibuat dapat terlihat pada gambar 8, 9 dan 10 .

Gambar 8 menunjukan implementasi antar muka untuk form login, yang digunakan oleh admin untuk dapat masuk ke sistem.

Gambar 9 merupakan form yang digunakan oleh admin untuk melihat data parkir yaitu kapasitas parkir, kendaran yang masuk dan keluar dari tempat parkir tersebut.

Gambar 10 merupakan form yang dipakai pengendara untuk melihat informasi parkir terdekat. Pada form ini akan terlihat lokasi parkir mana saja yang terdekat dengan pengendara.

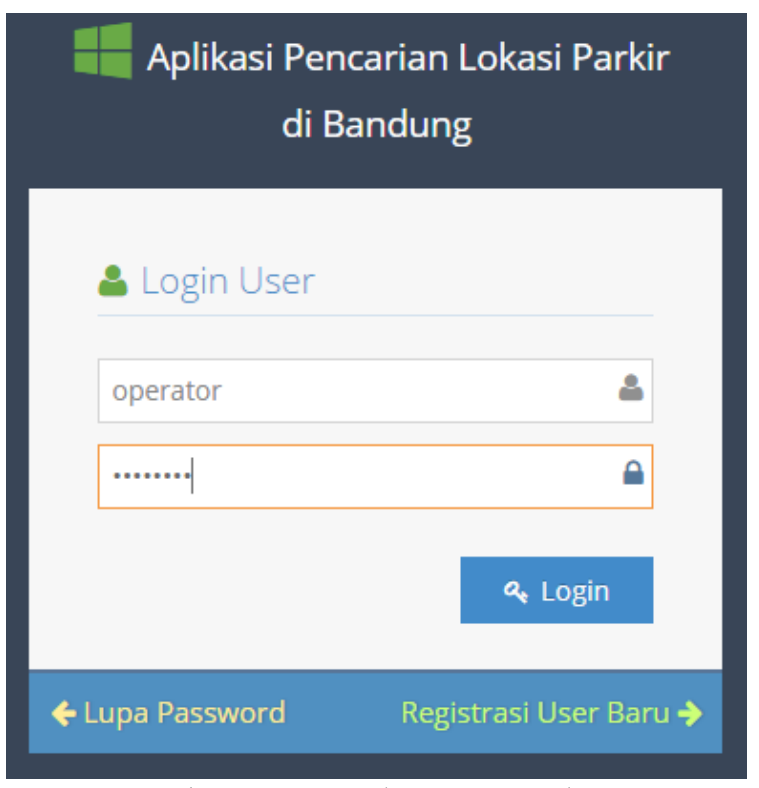

Gambar 8. Tampilan Login admin.

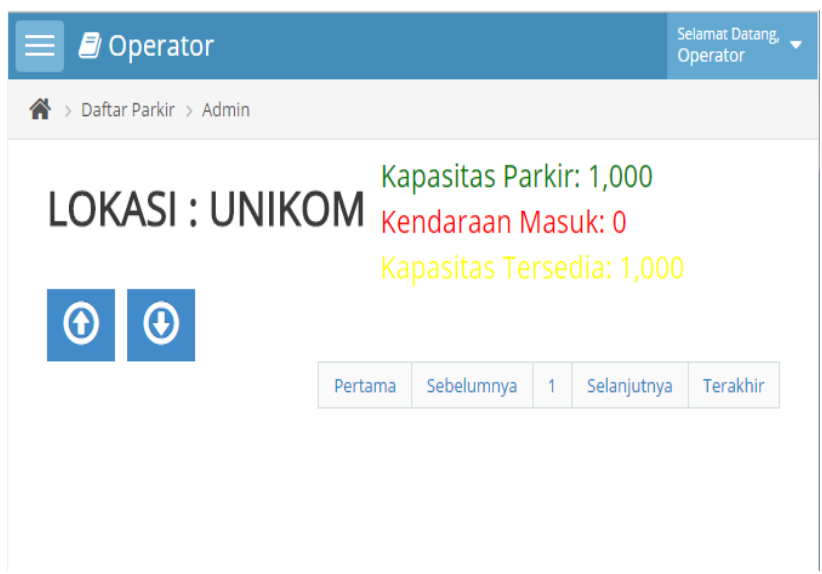

Gambar 9. Tampilan data parkir. 


\section{뭉}

\section{$\equiv \quad$ Parkiran Terdekat}

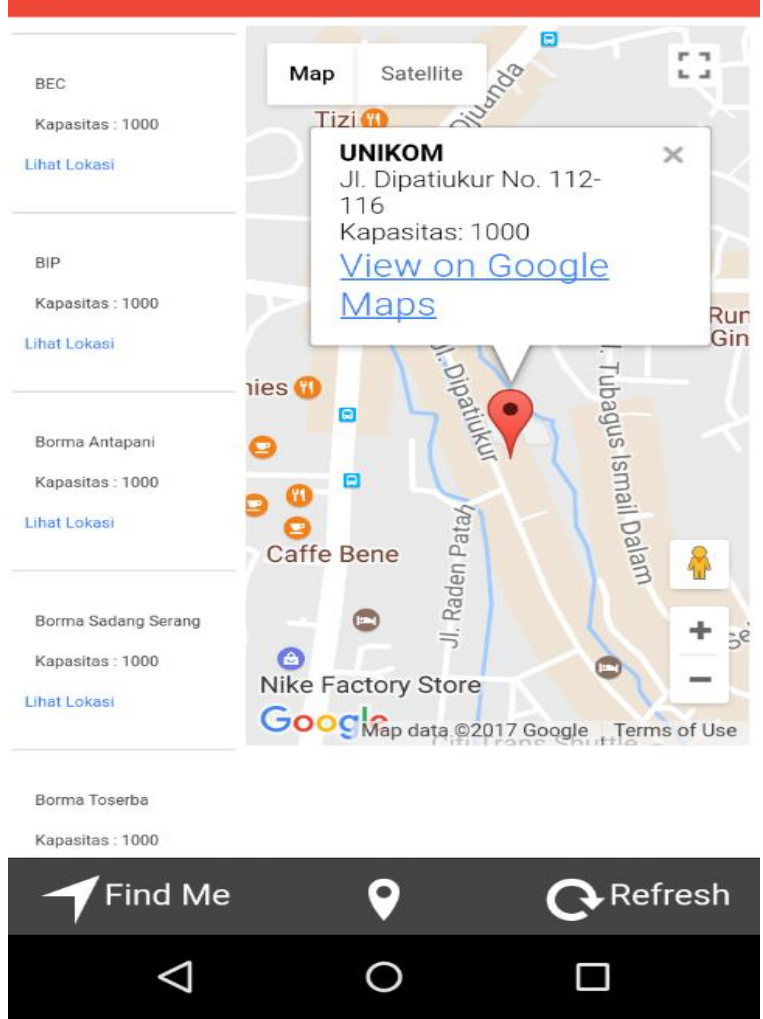

Gambar 10. Tampilan informasi parkir terdekat.

Pengujian yang dilakukan terhadap sistem untuk melihat apakah sistem yang dibuat sesuai dengan yang diharapkan adalah pengujian Alpha dan Beta. Metode blackbox merupakan metode yang digunakan pada pengujian alpha untuk melihat fungsional dari sistem. Komponen yang di uji pada aplikasi android terlihat pada tabel 2 .

Hasil dari pengujian tersebut bahwa secara fungsional sistem yang dibuat sudah dapat digunakan dan menghasilkan keluaran sesuai dengan yang diharapkan yaitu memberikan informasi tentang lokasi parkir terdekat dengan pengendara.

Untuk melihat apakah sistem yang dibuat memenuhi keutuhan dari pengguna, maka pengujian yang dilakukkan adalah pengujian beta. Pengujian dilakukan melalui wawancara dan kuisioner terhadap pengguna. Hasilnya didapatkan bahwa sistem yang dibuat sudah memenuhi kebutuhan pengguna yaitu memberikan kemudahan kepada pengendara untuk mencari lokasi parkir terdekat.

Untuk mengetahui efektifitas dan ketepatan data yang dihasilkan dari proses location based service untuk memberikan informasi lokasi parkir terdekat pada pengguna dilakukkan dengan membandingkan jarak menggunakan metode LBS dan jarak di Gmaps, tabel perbandingan terlihat pada tabel 2 .
Tabel 2. komponen uji aplikasi android.

\begin{tabular}{|c|c|}
\hline $\begin{array}{l}\text { Komponen } \\
\text { uji }\end{array}$ & Butir pengujian \\
\hline Menu & $\begin{array}{l}\text { Memilih Tombol Cari } \\
\text { Parkir } \\
\text { Memilih Tombol Parkiran } \\
\text { Terdekat }\end{array}$ \\
\hline Parkir & Menampilkan parkir dan \\
\hline Terdekat & $\begin{array}{l}\text { kapasitas dalam listView } \\
\text { Kapasitas Parkir pada } \\
\text { peta dan di beri icon }\end{array}$ \\
\hline & $\begin{array}{l}\text { Longitude dan latitude } \\
\text { user pada peta }\end{array}$ \\
\hline & $\begin{array}{l}\text { Navigasi ke Parkiran } \\
\text { yang di pilih }\end{array}$ \\
\hline \multirow[t]{3}{*}{ Cari Parkir } & $\begin{array}{l}\text { Menampilkan Parkir dan } \\
\text { kapasitas pada peta dan } \\
\text { diberi icon }\end{array}$ \\
\hline & $\begin{array}{l}\text { Menampilkan lokasi } \\
\text { parkir yang dicari }\end{array}$ \\
\hline & $\begin{array}{l}\text { Navigasi ke parkir yang } \\
\text { di pilih }\end{array}$ \\
\hline
\end{tabular}

Sedangkan komponen uji untuk aplikasi web terlihat pada tabel 3 .

Tabel 3. Komponen uji aplikasi web.

\begin{tabular}{|c|c|}
\hline $\begin{array}{c}\text { Komponen } \\
\text { uji }\end{array}$ & Butir pengujian \\
\hline \multirow{2}{*}{ Menu } & Memilih Tombol Login \\
\hline & Memilih Tombol Registrasi \\
\hline \multirow[t]{5}{*}{ Login } & Menampilkan form login \\
\hline & $\begin{array}{l}\text { Menampilkan tempat parkir } \\
\text { operator yang bertugas }\end{array}$ \\
\hline & $\begin{array}{l}\text { Menampilkan jumlah kapasitas } \\
\text { tersedia }\end{array}$ \\
\hline & $\begin{array}{l}\text { Menampilkan jumlah kendaraan } \\
\text { masuk }\end{array}$ \\
\hline & 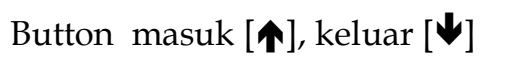 \\
\hline \multirow[t]{2}{*}{ Registrasi } & Menampilkan form registrasi \\
\hline & Button register \\
\hline
\end{tabular}


Tabel 4. Perbandingan Jarak.

\begin{tabular}{|c|c|c|c|c|c|}
\hline No & $\begin{array}{c}\text { Posisi User } \\
\text { (latitude,longtitude) }\end{array}$ & LBS & Jarak & $\begin{array}{l}\text { Lokasi Pada } \\
\text { Gmaps }\end{array}$ & Jarak \\
\hline \multirow{3}{*}{1} & Jl. Antapani & $\begin{array}{l}\text { Lucky } \\
\text { Square }\end{array}$ & $100 \mathrm{~m}$ & Lucky Square & $100 \mathrm{~m}$ \\
\hline & $(-6.91378,107.64399)$ & Yomart & $450 \mathrm{~m}$ & Yomart & $450 \mathrm{~m}$ \\
\hline & & BTM & $120 \mathrm{~m}$ & BTM & $900 \mathrm{~m}$ \\
\hline \multirow{3}{*}{2} & Jl. Ambon & $\begin{array}{l}\text { Riau } \\
\text { Junction }\end{array}$ & $45 \mathrm{~m}$ & Riau Junction & $45 \mathrm{~m}$ \\
\hline & $(-6.90683,107.61162)$ & Gramedia & $200 \mathrm{~m}$ & Gramedia & $350 \mathrm{~m}$ \\
\hline & & $\mathrm{BIP}$ & $220 \mathrm{~m}$ & $\mathrm{BIP}$ & $220 \mathrm{~m}$ \\
\hline 3 & $\begin{array}{l}\text { Jl. Diponegoro } \\
(-6.90122,107.62481)\end{array}$ & \multicolumn{4}{|c|}{ Tidak ada } \\
\hline 4 & $\begin{array}{l}\text { Jl. Sukajadi } \\
(-6.88334,107.59644)\end{array}$ & PVJ & $350 \mathrm{~m}$ & PVJ & $350 \mathrm{~m}$ \\
\hline 5 & $\begin{array}{l}\text { Jl. Supratman } \\
(-6.91269,107.63397)\end{array}$ & IBCC & $500 \mathrm{~m}$ & IBCC & $1.1 \mathrm{~km}$ \\
\hline 6 & $\begin{array}{l}\text { Jl.Cipaganti } \\
(-6.88409,107.601385)\end{array}$ & $\begin{array}{l}\text { Pizza Hut } \\
\text { Setiabudi }\end{array}$ & $290 \mathrm{~m}$ & $\begin{array}{l}\text { Pizza Hut } \\
\text { Setiabudi }\end{array}$ & $290 \mathrm{~m}$ \\
\hline \multirow{3}{*}{7} & Jl. Dago & $\begin{array}{l}\text { Dukomsel } \\
\text { Living }\end{array}$ & $350 \mathrm{~m}$ & Dukomsel & $350 \mathrm{~m}$ \\
\hline & $(-6.89766,107.61290)$ & $\begin{array}{l}\text { Plaza } \\
\text { Dago }\end{array}$ & $400 \mathrm{~m}$ & Living Plaza Dago & $1 \mathrm{~km}$ \\
\hline & & Superindo & $450 \mathrm{~m}$ & Superindo & $450 \mathrm{~m}$ \\
\hline \multirow[t]{2}{*}{8} & Jl. Dipatiukur & $\begin{array}{l}\text { McD } \\
\text { Dago }\end{array}$ & $87 \mathrm{~m}$ & McD Dago & $87 \mathrm{~m}$ \\
\hline & $(-6.88529,107.61427)$ & UNIKOM & $170 \mathrm{~m}$ & UNIKOM & $170 \mathrm{~m}$ \\
\hline 9 & $\begin{array}{l}\text { Jl. Cihampelas } \\
(-6.89014,107.60421)\end{array}$ & Ciwalk & $400 \mathrm{~m}$ & Ciwalk & $400 \mathrm{~m}$ \\
\hline 10 & $\begin{array}{l}\text { Jl. Tubagus Ismail } \\
(-6.88514,107.62037)\end{array}$ & & & idak ada & \\
\hline
\end{tabular}

Dari data pada pada tabel 4, perbandingan jarak dari proses location based service jika dibandingkan dengan aplikasi google maps tidak jauh berbeda namun pada saat posisi pengguna berada di Jl. Supratman dan Jl. Dago proses pada location based service berbeda dengan aplikasi google maps hal ini dikarenakan pada google maps menggunakan polyline pada jalan raya sedangkan aplikasi yang dibangun dengan location based service tidak menggunakan polyline pada jalan raya untuk menghitung jarak pada lokasi tujuan.

\section{KESIMPULAN}

Setelah dilakukkan pengujian terhadap sistem yang dibuat, maka dapat disimpulkan secara fngsional sistem yang dibuat sudah dapat digunakan dan menghasilkan keluaran yang diharapkan. Sistem yang dibuat juga sudah memberikan kemudahan bagi pengendara untuk mencari informasi lokasi parkir terdekat.

\section{UCAPAN TERIMA KASIH}

Penulis berterima kasih kepada Universitas Komputer Indonesia atas dukungan dalam menyelesaikan penelitian ini. 


\section{DAFTAR PUSTAKA}

[1] Y. Ardianto Pranata, Syaiful Nur Arif, "Perancangan Prototipe Sistem Parkir Cerdas," J. SAINTIKOM, 2015.

[2] P. A. Suthanaya, "Analisis Karakteristik Dan Kebutuhan Ruang Parkir Pada Pusat Perbelanjaan Di Kabupaten Badung," J. Ilm. Tek. Sipil, 2010.

[3] F. Kurniawan and E. Puspita, "Sistem Informasi Pelayanan Parkir Yang di Lengkapi Dengan Kamera," EEPIS Final Proj., 2010.

[4] A. Mudzakir and R. Arifudin, "Aplikasi Location Based Service Fasilitas Umum Berbasis Android," UNNES J. Math., 2015.

[5] K. R. Wahyu, A. K. Yapie, and E. S. Mulyani, "Aplikasi Location Based Service (LBS) Taman Mini Indonesia Indah (TMII) Berbasis Android," Semin. Nas. Apl. Teknol. Inf. 2013, 2013.
[6] M. S. Amri, "Membangun Sistem Navigasi Di Surabaya Menggunakan Google Maps Api," 2011.

[7] M. K. Ir. Yuni Sugiarti, Analisis \& Perancangan UML (Unified Modeling Language) Generated VB.6. 2013.

[8] Elista, "Pengembangan sistem," AKPRIND, 2015.

[9] K. Siau and L. Lee, "Are use case and class diagrams complementary in requirements analysis? An experimental study on use case and class diagrams in UML," Requir. Eng., 2004.

[10] T. Suratno, "Analisis penentu antarmuka terbaik berdasarkan eye tracking pada sistem informasi akademik universitas jambi," J. Penelit. Univ. Jambi Sei Sains, 2016. 